\title{
MicroRNAs in cancer metastasis and angiogenesis
}

\author{
Weiyang Lou ${ }^{1, *}$, Jingxing Liu ${ }^{2, *}$, Yanjia Gao $^{3, *}$, Guansheng Zhong ${ }^{1}$, Danni Chen ${ }^{1}$, \\ Jiaying Shen ${ }^{1}$, Chang Bao ${ }^{1}$, Liang $\mathrm{Xu}^{4}$, Jie Pan ${ }^{1}$, Junchi Cheng ${ }^{5}$, Bisha Ding ${ }^{1}$ and \\ Weimin Fan ${ }^{1,6}$ \\ ${ }^{1}$ Program of Innovative Cancer Therapeutics, Division of Hepatobiliary and Pancreatic Surgery, Department of Surgery, First \\ Affiliated Hospital, College of Medicine, Zhejiang University, Key Laboratory of Combined Multi-Organ Transplantation, \\ Ministry of Public Health, Key Laboratory of Organ Transplantation, Zhejiang Province, Hangzhou 310003, China \\ ${ }^{2}$ Department of Intensive Care Unit, Changxing People's Hospital of Zhejiang, Zhejiang Province, Huzhou 313100, China \\ ${ }^{3}$ Department of Anesthesiology, International Hospital of Zhejiang University, Shulan (Hangzhou) Hospital, Zhejiang \\ Province, Hangzhou 310003, China \\ ${ }^{4}$ Clinical Research Center, First Affiliated Hospital, College of Medicine, Zhejiang University, Zhejiang Province, Hangzhou \\ 310003, China \\ ${ }^{5}$ Department of Chemotherapy, Zhejiang Cancer Hospital, Zhejiang Province, Hangzhou 310003, China \\ ${ }^{6}$ Department of Pathology and Laboratory Medicine, Medical University of South Carolina, Charleston, SC 29425, USA \\ *These authors have contributed equally to this work
}

Correspondence to: Weimin Fan, email: fanw@zju.edu.cn

Keywords: angiogenesis; cancer; microRNAs; metastasis; therapy

Received: July 27, $2017 \quad$ Accepted: November 17, $2017 \quad$ Published: December 11, 2017

Copyright: Lou et al. This is an open-access article distributed under the terms of the Creative Commons Attribution License 3.0 (CC BY 3.0), which permits unrestricted use, distribution, and reproduction in any medium, provided the original author and source are credited.

\section{ABSTRACT}

Cancer metastasis is a malignant process by which tumor cells migrate from their primary site of origin to other organs. It is the main cause of poor prognosis in cancer patients. Angiogenesis is the process of generating new blood capillaries from pre-existing vasculature. It plays a vital role in primary tumor growth and distant metastasis. MicroRNAs are small non-coding RNAs involved in regulating normal physiological processes as well as cancer pathogenesis. They suppress gene expression by specifically binding to the $3^{\prime}$-untranslated region ( $3^{\prime}$-UTR) of their target genes. They can thus act as oncogenes or tumor suppressors depending on the function of their target genes. MicroRNAs have shown great promise for use in anti-metastatic cancer therapy. In this article, we review the roles of various miRNAs in cancer angiogenesis and metastasis and highlight their potential for use in future therapies against metastatic cancer.

\section{INTRODUCTION}

MicroRNAs (miRNAs, miRs) are a class of small endogenous non-coding RNAs, 21-25 nucleotides in length, which are highly conserved in evolution and usually exist as single copy or multi copy genes or as a gene cluster [1]. They are transcribed as long primary transcripts, which are subsequently processed by Drosha and Dicer [2]. Eventually, the mature miRNAs form a RNA-inducing silencing complex (RISC)-miRNA functional unit, which regulates the expression of nearly
$30 \%$ of the known human genes [3]. The miRNAs basepair with specific binding sites in the 3'-untranslated region (3'UTR) of their target messenger RNA (mRNA) and suppress gene expression at the post-transcriptional and translational levels [4]. The miRNAs are involved in a variety of biological processes such as cell proliferation, differentiation, apoptosis, survival, invasion, and migration [5-7]. Many studies have demonstrated that mutations in miRNA-encoding genes or deregulated expression of miRNAs are integral to many human diseases including cancers. 
Angiogenesis is defined as the formation of new blood vessels from pre-existing capillaries or postcapillary venules [8]. Angiogenesis plays an important role in embryonic development as well as post-natal life [9]. Aberrant angiogenesis is central to many angiogenic diseases such as age-related macular degeneration (AMD) $[10,11]$, rheumatoid arthritis (RA) [12-14] and endometriosis (EM) $[15,16]$. Aberrant angiogenesis is also critical for cancer metastasis [17-21].

Cancer is highly prevalent because of deterioration of the global ecological environment and the extension of life expectancy. In 2012, 14.1 million new cases of cancer were reported worldwide [22]. Unlike benign lesions, cancer subsequently metastasizes to distant tissues and organs, resulting in morbidity and mortality [23]. Although great advances have been made in the diagnosis and treatment of cancer metastasis, the prognosis of metastatic cancer patients remains extremely poor. Therefore, there is an urgent need to develop novel therapeutic approaches to treat cancer metastasis.

The role of miRNAs in anti-angiogenic therapy has emerged as a promising approach to treat metastatic cancers. In this review, we highlight recent findings about the role of miRNAs and their targets in cancer angiogenesis and metastasis. We also discuss the implications of miRNA-based therapeutic strategies targeting angiogenesis in metastatic cancer.

\section{BIOGENESIS OF MIRNA}

MiRNAs are non-coding, small, single-stranded RNAs that are derived from the primary transcript called pri-miRNA, which is transcribed by RNA polymerase II [24]. The pri-miRNAs are characterized by the presence of a single or multiple imperfect hairpin structures with a stem of approximately 33 base-pairs [1]. Subsequently, the primiRNA precursor undergoes a two-step processing pathway, mediated by two ribonucleases, Drosha and Dicer belonging to the RNase III family [2]. In the nucleus, Drosha cleaves the pri-miRNA to generate an approximately 70 nucleotides long pre-miRNA, which is exported to the cytoplasm via an exportin-5-dependent mechanism [25-27]. In the cytoplasm, the pre-miRNA is further processed by Dicer to generate a mature, functional, double-stranded miRNA [28]. Then, the guide strand or mature miRNA is integrated into a multi-protein complex, RISC, which contains the argonaute (AGO) protein that plays a central role in RNA silencing. RISC uses the guide strand to target complementary 3'-UTR of mRNA via WatsonCrick base pairing $[29,30]$. The other strand which is known as miRNA* or passenger strand is eventually degraded [31]. The miRNA binding to the 3'-UTR leads to mRNA degradation or translational repression, the extent of which is dependent on the degree of complementation. Besides, RISC can also target 5'-UTR of mRNA and activate translation [32]. The biogenesis of miRNA is shown in Figure 1.

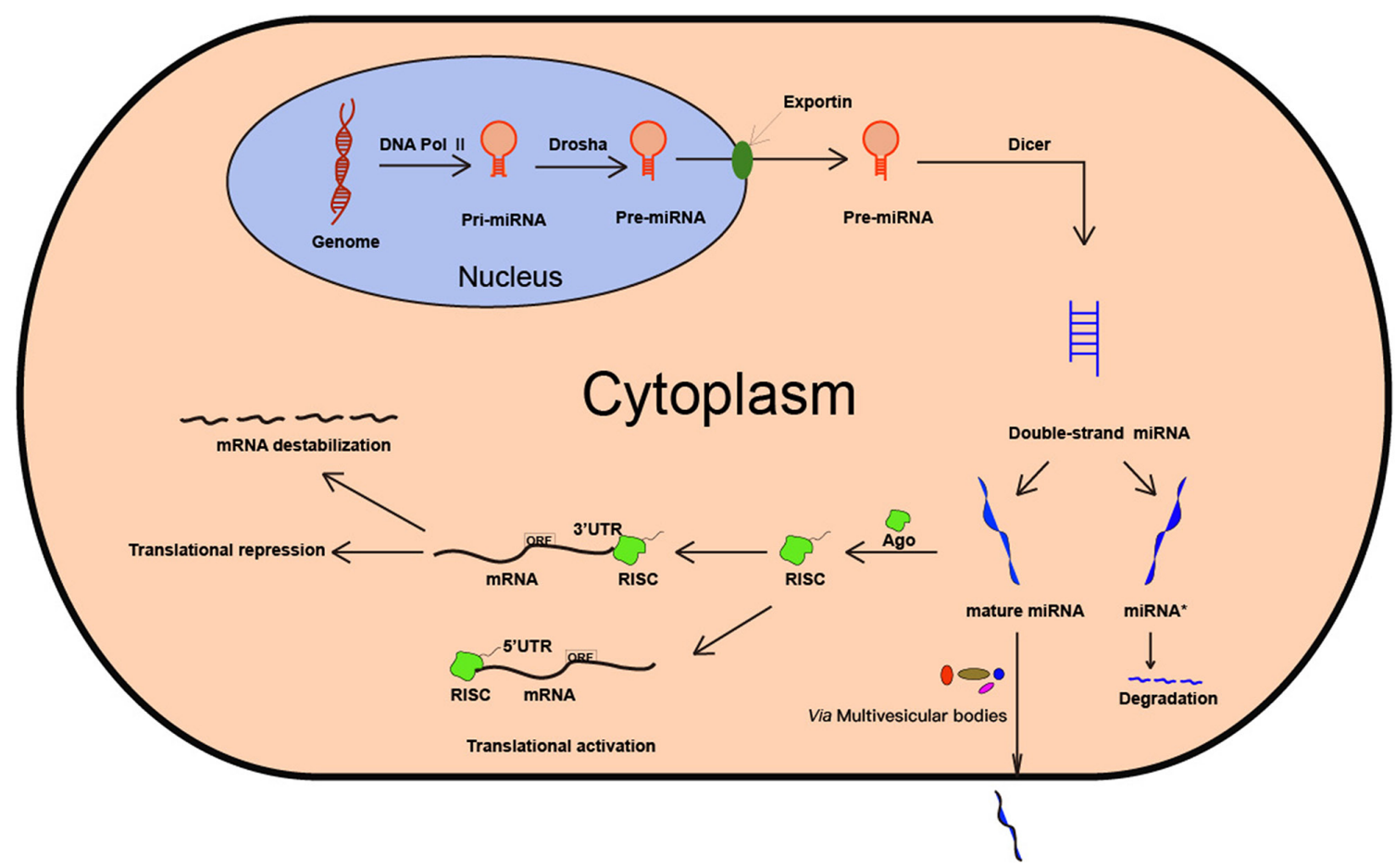

Figure 1: Biogenesis of miRNA. MiRNA is first transcribed by RNA Pol II. Then, the pri-miRNA is processed by the enzyme Drosha and Dicer. The mature miRNA is integrated into RISC, thereby leading to mRNA degradation, translational repression or translational activation. 


\section{CANCER ANGIOGENESIS}

Avascular, vascular and metastatic stages are the three stages of cancer. During the avascular stage, the tumor obtains nutrients and oxygen needed for growth by passive diffusion. However, the tumor growth is only about 1-2 $\mathrm{mm}$ in diameter without sufficient blood supply provided by angiogenesis [33]. Thus, angiogenesis is essential for uncontrolled growth of tumors. Initially, the pro- and anti-angiogenic factors are balanced in the tumor microenvironment. Cancer angiogenesis is similar to physiological angiogenesis and involves formation of new blood vessels through proliferation, migration and differentiation of endothelial cells (ECs) using pre-existing vascular structures [34]. Cancer angiogenesis is a complex multi-stage process involving degradation of vascular basement membrane and extracellular matrix, proliferation and migration of vascular endothelial cells, formation of a new vessel lumen and vessel branches, and maturation of the new vessel [35]. This process is activated due to low oxygen microenvironment in a growing cancer [35]. In response to the hypoxic environment, cancer cells undergo an angiogenic switch. Thus, the production of pro-angiogenic factors such as vascular endothelial growth factor (VEGF) and proteolytic enzymes [36] is increased and the induction of anti-angiogenic factors including angiopoietin 2 [8], angiostatin [37] and endostatin [38] is attenuated. Subsequently, the increased production of pro-angiogenic factors results in the activation of EC proliferation, differentiation, and migration. Eventually, a capillary network is successfully set up. The process of cancer angiogenesis is shown in Figure 2.

Unlike physiological angiogenesis, cancer angiogenesis is an inefficient process with sub-optimal perfusion, lack of vessel integrity and disorganized vessel network [39]. However, the newly-formed premature vessels provide the growing tumor tissue with adequate metabolites [40]. The immature structure of newly-formed blood vessels results in cancer cells gaining access to circulation. Moreover, the irregular and disorganized structure of blood vessels results in a high density vascular bed, which enhances the contact area between cancer and circulation, resulting in greater access for cancer cells to enter into circulation and promote distant metastases [40]. The number of metastasis sites positively correlate with the number of cancer cells initially entering the circulation [41]. Taken together, cancer angiogenesis not only acts as a bridge between primary cancer and circulation, but also plays a significant role in cancer metastasis. Metastatic cancer also undergoes three stages of development similar to primary cancer, which includes the avascular, vascular and metastatic stages. This vicious cycle results in morbidity and mortality of cancer patients. Therefore, cancer angiogenesis is pivotal to both initiation and progression of metastatic cancer.

\section{CANCER METASTASIS}

Metastasis is closely related to poor prognosis of cancer patients [42]. It is the leading cause of cancerrelated deaths and therefore critical for early diagnosis and treatment. About $50 \%$ of all cancer patients show clinically detectable metastasis at the time of diagnosis. However, micrometastases remain undetectable in a large number of cancer patients by the currently employed techniques [43].

Metastasis is defined as the process by which cancer cells translocate from their primary cancer location to distant organs via the circulatory system or body cavities and subsequently establish a secondary cancer at the new tissue site [44]. As shown in Figure 3, cancer metastasis is an intricate process involving a number of sequential steps like (1) alteration and rearrangement of cytoskeleton, (2) degradation of extracellular matrix, (3) local invasion, (4) intravasation, (5) transport and survival in the circulatory system, (6) extravasation, and (7) settlement and proliferation in a new site [45]. Cancer metastasis has been well investigated in clinical studies. Despite being the central focus of clinical research, the specific mechanism of cancer metastasis has not yet been fully elucidated. It is widely thought that cancer metastasis occurs in association with the degradation of extracellular matrix [46], epithelial-mesenchymal transition (EMT) [47-49], overexpression of matrix metalloproteinases (MMPs) [50, 51], immune evasion [52], the homing of circulating cancer cells and cancer stem cells (CSCs) [53] as well as cancer microenvironment and angiogenesis [54].

\section{DYSREGULATED MIRNAS IN CANCER ANGIOGENESIS AND METASTASIS}

\section{Anti-angiogenic and anti-metastatic miRNAs}

\section{MiRNAs targeting VEGF signaling}

Vascular endothelial growth factor (VEGF) consists of VEGFA, VEGFB, VEGFC, VEGFD and placenta growth factor (PGF) [55]. Ectopic expression of VEGF partly accounts for cancer progression because of its involvement in cancer angiogenesis and metastasis [56, 57]. Many miRNAs regulate the VEGF expression. MiRNA-29c overexpression inhibits angiogenesis by downregulating VEGF [58]. Moreover, upregulation of miRNA-29c suppresses in vitro glioma cell migration and invasion due to reduced MMP-2 levels [58]. Wang et al. reported that the low expression of miRNA-195 promotes angiogenesis and metastasis of HCC via VEGF and the pro-metastatic factors, VAV2 and CDC42 [59]. Ghosh et al. showed that miRNA-199a-3p was downregulated in HCC tissues; its overexpression suppressed cancer growth, angiogenesis and lung metastasis by suppressing VEGFA, VEGFR1, 
VEGFR2, HGF and MMP2 [60]. Tu et al. showed that miRNA-497 inhibited breast cancer angiogenesis by targeting VEGFR2 [61]. Twist-induced downregulation of miRNA-497 promoted angiogenesis and metastasis of pancreatic cancer and was associated with high levels of VEGFA [62]. Besides, miRNA-497 suppressed HCC angiogenesis and metastasis by inhibiting VEGFA [63].

\section{MiRNAs targeting HIF signaling}

Hypoxia-inducible factor (HIF) is a transcriptional factor that responds to low oxygen levels. The dysregulation of HIF is vital for the formation of blood vessels in cancer, thereby accelerating cancer progression. Cha et al. showed that overexpression of miRNA-519c attenuated angiogenic activity of endothelial cells and

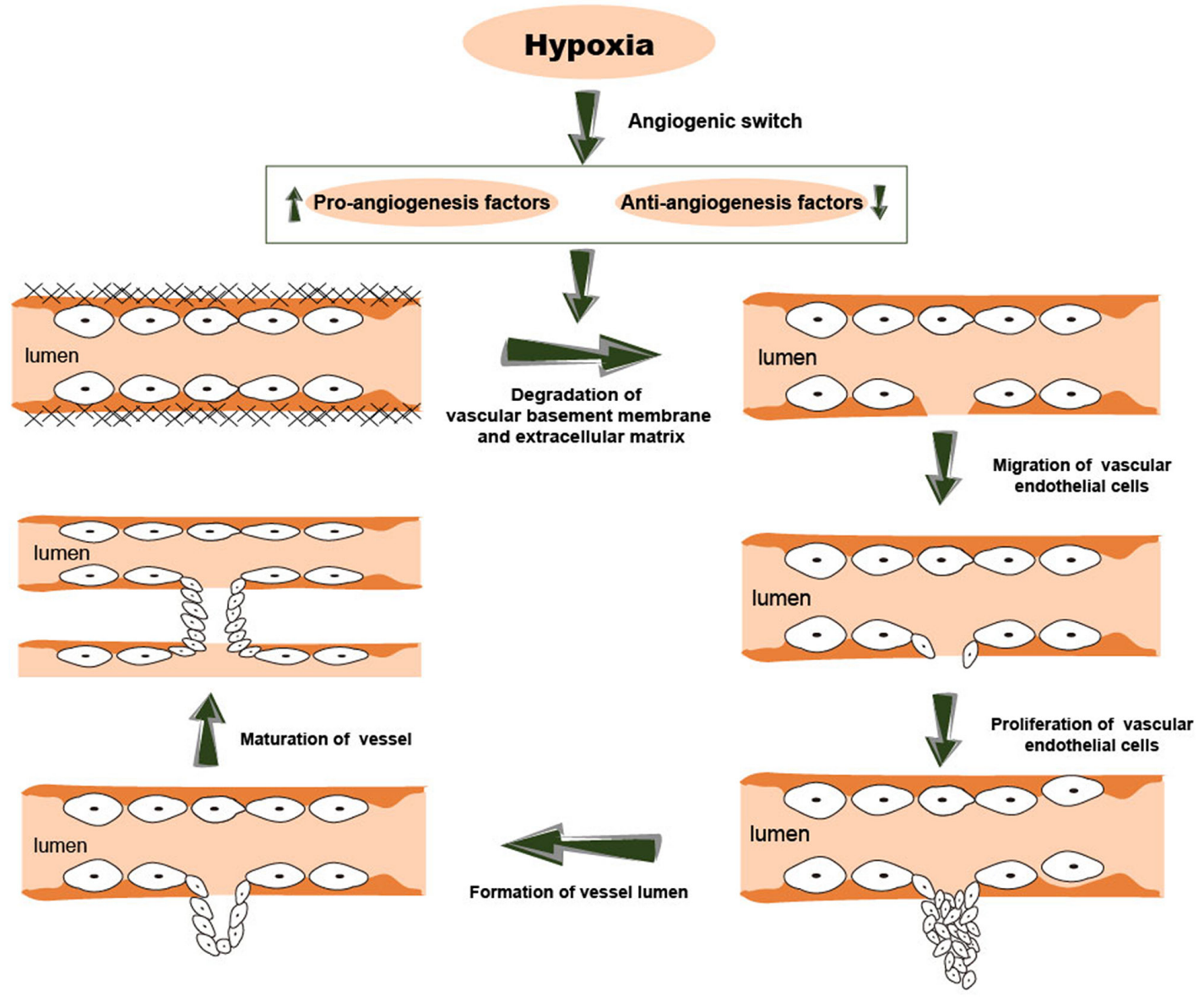

Figure 2: The process of cancer angiogenesis. This process is usually activated in a low oxygen microenvironment. Cancer angiogenesis involves multiple steps, including degradation of vascular basement membrane and extracellular matrix, proliferation and migration of vascular endothelial cells, formation of a new vessel lumen and vessel branches, and maturation of the new vessels.

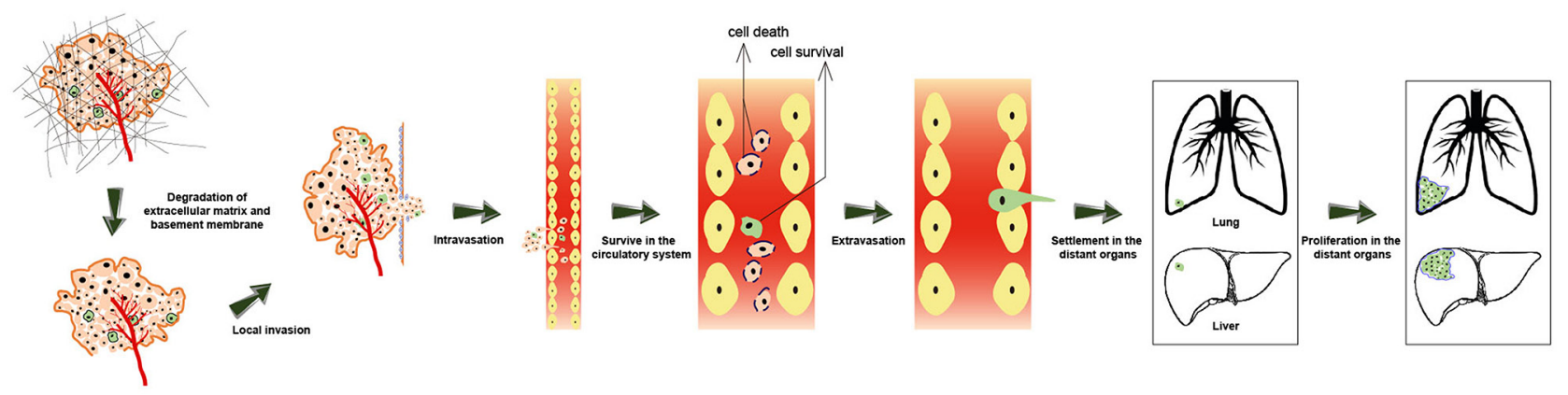

Figure 3: The process of cancer metastasis. A series of sequential steps are involved in cancer metastasis, such as alteration and rearrangement of cytoskeleton, degradation of extracellular matrix, local invasion, intravasation, transfer and survive in the circulatory system, extravasation, settlement and proliferation in a new organ (like lung and liver). 
suppressed angiogenesis and metastasis by reducing HIF-1 $\alpha$ levels [64]. Therefore, cancer patients with high miRNA-519c levels had better prognosis [64]. Zhang et al. showed that miRNA-145 directly targeted HIF-2 $\alpha$, thereby inhibiting angiogenesis and metastasis of neuroblastoma [65]. Moreover, miRNA-145 negatively regulated gastric cancer angiogenesis and metastasis by suppressing Ets-1 transcription factor [66]. Mutations in p53 are positively correlated with cancer growth and angiogenesis because it regulates apoptosis, DNA repair, and cell-cycle progression via transcription of several miRNAs [67]. Yamakuchi et al. showed that p53 activated miRNA-107 transcription, which suppressed expression of HIF-1 $\beta$, thereby inhibiting cancer angiogenesis, growth, and VEGF expression [68].

\section{MiRNAs targeting angiopoietin-2 signaling}

Angiopoietin-2 is a member of angiopoietins, which is mainly produced by ECs [69]. It facilitates VEGF-induced angiogenesis in multiple cancers. Therefore, inhibiting angiopoietin-2-related pathway suppresses cancer angiogenesis and metastasis [70, 71]. Ting et al. demonstrated that miRNA-542-3p inhibited angiopoietin-2 by directly binding to its 3'UTR [72]. Furthermore, miRNA-542-3p is a promising prognostic marker to monitor progression of breast cancer because its expression negatively correlates with clinical progression of stage III and stage IV breast cancer patients [72]. In HCC, downregulation of miRNA-542-3p is associated with intrahepatic metastasis and venous infiltration [73]. Fan et al. showed that reduced miRNA-543 levels correlated with colorectal cancer (CRC) metastasis [74]. In osteosarcoma, the expression of miRNA-543 was inhibited by connective tissue growth factor (CTGF), which resulted in increased Angiopoietin-2 levels that induced osteosarcoma angiogenesis [75].

\section{MiRNAs targeting MMP signaling}

Matrix metalloproteinases (MMPs) are calciumdependent zinc-containing endopeptidases, which are essential for tissue remodeling associated with cancer angiogenesis and metastasis. MiRNA-9 induction inhibited MMP14 levels, which resulted in reduced angiogenesis, invasion and metastasis of neuroblastoma cells, both in vitro and in vivo [76]. Li et al. showed that MMP-14 was also a direct target of miRNA-181-5p in breast cancer cells, which resulted in attenuating breast cancer cell migration, invasion and angiogenesis [77]. Moreover, Ghosh et al. demonstrated that miRNA-199a$3 \mathrm{p}$ suppressed HCC growth, invasion, migration and angiogenesis by partially targeting MMP2 [60].

\section{MiRNAs targeting LRP-6 signaling}

Low-density lipoprotein receptor-related protein 6 (LRP6) and LRP5 are part of the LRP5/LRP6/Frizzled co-receptor, which is involved in the Wnt/ $\beta$-catenin signaling [78]. LRP6 promotes cancer metastasis by participating in the canonical Wnt pathway in a variety of cancers such as triple negative breast cancer [79]. Fan et al. found that miRNA-454 inhibited cancer angiogenesis and metastasis by targeting LRP6 in pancreatic ductal adenocarcinoma (PDAC) [80]. The miRNA-454 overexpressing PDAC cells suppressed formation of capillary tube-like structures by HUVEC cells, thereby showing its role in inhibiting angiogenesis [80]. Xenograft experiments demonstrated decreased lung metastasis from miRNA-454 overexpressing PDAC cells than controls [80]. In another study, Du et al. showed that miRNA126-3p partially suppressed angiogenesis and metastasis of HCC by targeting LRP6 [81]. Moreover, Sasahira et al. demonstrated that miRNA-126 inhibited metastasis in OSCC by suppressing VEGFA [82]. Therefore, miRNA126-3p and miRNA-454 as well as LRP6 are potential targets for the treatment of cancer angiogenesis and metastasis.

\section{MiRNAs targeting IL-6 signaling}

Interleukin 6 (IL-6) is an inflammatory cytokine, which plays a role in cancer metastasis by downregulating E-cadherin [83]. Higher levels of serum IL-6 in patients with advanced or metastatic cancer suggest that it promotes metastasis. Yang et al. demonstrated that miRNA-26a inhibited in vitro HCC cell invasiveness and migration as well as in vivo metastasis by downregulating IL-6 [84]. Moreover, miRNA-26a also suppressed HCC angiogenesis [85]. MiRNA-451 is downregulated in human osteosarcomas and is implicated in suppressing angiogenesis and metastasis by targeting IL-6R [86]. Moreover, upregulation of miRNA-451 suppressed in vitro migration and angiogenesis of osteosarcoma cells [86]. Liu X et al. showed that miRNA-451 suppressed HCC angiogenesis by blocking the IL-6R/Stat3 pathway [87]. Thus, miRNA-451 demonstrates therapeutic potential as an anti-angiogenesis and anti-metastatic target.

\section{Other miRNAs}

\section{MiRNA-34a}

CD44 antigen is a cell-surface glycoprotein that is relevant to cancer therapy and prognosis because of its role in cell-cell interactions as well as cell adhesion and migration [88]. Yu et al. reported low miRNA-34a levels in human bladder cancer tissues [89]. Moreover, overexpression of miRNA-34a inhibited angiogenesis and metastasis of bladder cancer cells by targeting CD44 [89]. Therefore, miRNA-34a and CD44 are potential anti-angiogenic and anti-metastatic therapeutic targets in bladder cancer patients.

\section{MiRNA-101}

Smits et al. showed that miRNA-101 inhibited proliferation, angiogenesis and migration of glioblastoma cells by targeting enhancer of zeste homolog 2 (EZH2) 
[90]. Moreover, Tang et al. showed that miRNA-101 was downregulated in nasopharyngeal carcinoma tissues and cell lines. They further showed that overexpression of miRNA-101 suppressed angiogenesis and lung metastasis by targeting Integrin subunit alpha 3 (ITGA3) [91].

\section{MiRNA-124}

Wang et al. demonstrated that upregulation of miRNA-124 attenuated in vitro migration, invasion and vasculogenic mimicry of bladder cancer cells by downregulating ubiquitin-like with PHD and RING finger domain 1 (UHRF1) [92]. In cervical cancer, miRNA-214 inhibited vasculogenic mimicry, migration and invasion by suppressing angiomotin-like protein, AmotL1 [93]. These studies imply that miRNA-124 and its related targets are potential targets for anti-angiogenic and anti-metastatic cancer therapy.

\section{MiRNA-135a}

MiRNA-135a is a tumor suppressor, which is reported to be downregulated in human prostate and gall bladder cancers [94, 95]. Cheng et al. reported that miRNA-135a levels were downregulated in gastric cancer tissues and cell lines [96]. They showed that miRNA-135a inhibited gastric cancer angiogenesis and metastasis by targeting the focal adhesion kinase (FAK), which regulates VEGF signaling [96]. Wang et al. showed low miRNA-135 expression in NSCLC tissues [97]. Overexpression of miRNA-135 suppressed in vitro NSCLC cell proliferation, invasion, migration and angiogenesis and induced cell apoptosis by blocking the IGF-1/PI3K/Akt signaling pathway [97].

\section{MiRNA-218}

Alajez et al. showed that miRNA-218 inhibited nasopharyngeal cancer progression by targeting survivin and SLIT2-ROBO1 pathway [98]. MiRNA-218 expression was silenced by DNA methylation in oral squamous cell carcinoma [99]. These findings suggested that miRNA-218 was a tumor suppressor. Zhang et al. showed decreased expression of miRNA-218 in gastric cancer [100]. MiRNA-218 inhibited gastric cancer angiogenesis and metastasis by downregulating ROBO1 [101]. These data suggested that miRNA-218 suppressed gastric cancer metastasis by inhibiting angiogenesis via a ROBO1dependent mechanism.

\section{MiRNA-320}

Neuropilin 1 has been implicated in cancer angiogenesis and metastasis because of its interaction with VEGFA [102-104]. Neuropilin 1 is a target of miRNA-320 and its expression inversely correlates with miRNA-320 in oral squamous cell carcinoma (OSCC) $[105,106]$. The overexpression of miRNA-320 suppresses OSCC angiogenesis [105]. Furthermore, inhibition of miRNA-320 accelerates the growth and metastasis of cholangiocarcinoma suggesting that it suppresses angiogenesis by depleting neuropilin 1 levels [106]. These results demonstrate the potential of miRNA-320 and neuropilin 1 as anti-angiogenic or anti-metastatic cancer therapeutic targets for OSCC.

\section{MiRNA-409-3p}

Angiogenin or ribonuclease 5 is a potent stimulator of angiogenesis [107, 108]. Weng et al. showed that overexpression of miRNA-409-3p decreased angiogenin mRNA and protein levels by binding to its 3 '-UTR, thereby inhibiting fibrosarcoma vascularization and metastasis [109]. Conversely, knockdown of miRNA-409$3 p$ increased fibrosarcoma progression [109]. Therefore, miRNA-409-3p is a potential target in fibrosarcoma therapy.

\section{MiRNA-590-5p}

Multiple studies have demonstrated the role of miRNA-590-5p in the initiation and progression of CRC [110-112]. Zhou et al. showed decreased miRNA-590-5p expression in human colorectal cancer (CRC) cells and tissues, demonstrating that miRNA-590-5p was a tumor suppressor in CRC [113]. Subsequent in vivo studies revealed that miRNA-590-5p knockdown promoted cancer angiogenesis, growth and lung metastasis, whereas its overexpression attenuated $\mathrm{CRC}$ progression by regulating nuclear factor 90 (NF90)/VEGFA signaling axis [113]. These data indicate that miRNA-590-5p is a potential target for human CRC therapy.

\section{MiRNA-1301}

There is increasing evidence that miRNA-1301 prevents angiogenesis and metastasis in hepatocellular carcinoma patients. MiRNA-1301 suppresses dissemination and metastasis of HCC cells via p53 [114]. Yang et al. demonstrated that miRNA-1301 was downregulated in HCC tissues and cell lines [115]. Moreover, miRNA-1301 targets B-cell CLL/lymphoma 9 (BCL9), which regulates $\beta$-catenin cofactors that are necessary for the transcription of Wnt target genes [115, 116]. Further studies demonstrated that miRNA-1301 inhibited hepatocellular carcinoma cell migration, invasion, and angiogenesis by decreasing $\mathrm{Wnt} / \beta$-catenin signaling via BCL9 [115].

\section{Pro-angiogenic and pro-metastatic miRNAs}

\section{MiRNA-93}

The miRNA-106b-25 cluster, which is a paralogue of miRNA-17-92 and miRNA-106a-363 clusters, consists of three mature miRNAs, namely miRNA-106b, miRNA-93, and miRNA-25 [117, 118]. The miRNA-106b-25 cluster is highly expressed in several human cancers and performs oncogenic function by suppressing P21 and Bim [119]. Jonathan et al. demonstrated that the miRNA-106b-25 cluster regulated the function of angiogenic bone marrow- 
derived stromal cells and endothelial cells and therefore was closely connected with angiogenesis [120]. Moreover, miRNA-93 promoted cancer growth and angiogenesis by targeting integrin- $\beta 8$ [121]. Furthermore, miRNA-93 enhanced human breast cancer angiogenesis and promoted metastasis to lung tissue by suppressing the large tumor suppressor homology 2 (LATS2) protein, which is associated with cancer cell death [122]. Altogether, inhibition of miR-93 is a feasible approach to mitigate breast cancer angiogenesis and metastasis.

\section{MiRNA-378}

MiRNA-378 is widely recognized as an oncogene that promotes cancer growth, survival, angiogenesis and metastasis [123]. The levels of miRNA-378 are frequently increased in cancer tissue or serum of cancer patients and associated with poor prognosis [124, 125]. Lee et al. demonstrated that miRNA-378 enhanced U87 cancer cell survival and promoted cancer growth and angiogenesis [126]. SuFu, a negative regulator of Sonic Hedgehog (SHH) signaling, which facilitates large vessel formation by inducing the expression of pro-angiogenic cytokines including VEGF and Ang-1 is a miRNA-378 target [126]. FUS-1 is another direct target of miRNANA-378. FUS-1 overexpression reverses cancer cell survival and angiogenesis effects mediated by miRNA-378. Moreover, miRNA-378 is associated with brain metastasis of nonsmall cell lung cancer cells [127]. Furthermore, stable miRNA-378 overexpression increases non-small lung carcinoma growth, angiogenesis and metastasis by enhancing the expression of VEGF and Ang-1 [123]. These findings suggest that miRNA-378 is a potential target for anti-metastatic cancer therapy.

\section{MiRNA-155}

MiRNA-155 is frequently overexpressed in various types of human cancer and is linked to cancer angiogenesis and metastasis [128, 129]. Kong et al. found that the ectopic expression of miRNA-155 accelerated cancer angiogenesis and correlated with poor prognosis in triplenegative breast cancer [130]. MiRNA-155 overexpression induced network formation, proliferation, invasion and migration of human umbilical vein endothelial cells (HUVEC). There was an inverse correlation between miRNA-155 and Von Hippel-Lindau (VHL) expression. VHL overexpression rescued angiogenesis induced by miRNA-155, which indicated that miRNA-155 promoted angiogenesis by targeting VHL. The VHL protein is a component of the protein complex that possesses ubiquitin ligase E3 activity and is involved in the ubiquitination and degradation of HIF [131]. Petrovic et al. suggested that miRNA-155 promoted lymph node metastasis by investigating miRNA-155 levels in normal breast tissue, non-invasive and invasive breast carcinoma, and metastatic lymph nodes [132]. Johansson et al. showed that miRNA-155 targeted CCAAT-enhancer binding protein beta $(\mathrm{C} / \mathrm{EBP} \beta)$, which is a differentiation factor for the mammary epithelium and related to epithelialmesenchymal transition (EMT) [133]. These results suggest that miRNA-155 is a potential therapeutic target to treat angiogenesis and metastasis of breast cancer.

\section{MiRNA-494}

MiRNA-494 is overexpressed in many cancers and plays a key role in cancer development and progression [134, 135]. Faversani et al. reported that miRNA-494 expression correlated with poor prognosis of lung cancer patients. Its overexpression enhanced motility and metastasis of lung cancer cells by activating NOTCH1 pathway and repressing PTEN/PI3K/AKT signaling [136]. Mao et al. showed that high miRNA-494 levels in lung cancer facilitated migration of vascular endothelial cells (ECs) and promoted angiogenesis by targeting PTEN, thereby activating Akt/e-NOS pathway. Moreover, intra-tumoral administration of miRNA-494 antagonists effectively suppressed lung cancer angiogenesis [137]. Therefore, miRNA-494 is a promising target for antiangiogenic and anti-metastatic therapy for lung cancer patients.

\section{MiRNA-296}

The high expression of pro-angiogenic growth factor receptors on endothelial cells is a common feature of angiogenic blood vessels. These receptors include vascular endothelial growth factor receptor (VEGFR) and plateletderived growth factor receptor (PDGFR), which are targets for anti-angiogenic therapies [138, 139]. Wurdinger et al. reported that miRNA-296 regulated levels of VEGFR2 and PDGFRß in angiogenic endothelial cells [140]. Moreover, they showed that Hepatocyte growth factor-regulated tyrosine kinase substrate (HGS), which degrades PDGFRß and VEGFR2 was highly repressed by miRNA-296 [140142]. While miRNA-296 overexpression decreased HGS protein levels and increased PDGFRß and VEGFR2 levels that promoted angiogenesis, miRNA-296 antagonists attenuated cancer angiogenesis [140]. Additionally, clinical tissue microarrays showed that miRNA-296 was frequently upregulated in prostate cancer. Systemic delivery of miRNA-296 inhibitor decreased the incidence of pulmonary cancer metastasis by directly binding to the 3'UTR of intercellular adhesion molecule 1 (ICAM1) [143]. Therefore, miRNA-296 is a potential target in antiangiogenic and anti-metastatic cancer therapy.

\section{MiRNA-1246}

MiRNA-1246 is a p53 transcriptional target, which participates in the regulation of the known anticancer functions of $\mathrm{p} 53$, such as activating DNA repair proteins and initiating apoptosis [144]. MiRNA-1246 promotes the development and progression of colorectal cancer [145]. Wang et al. demonstrated that miRNA-1246 overexpressing colorectal cancer cells exhibited higher invasive and migration capacity than controls [146]. In colorectal cancer tissues, miRNA-1246 levels were 
Table 1: Summary of dysregulated miRNAs in cancer angiogenesis and metastasis

\begin{tabular}{|c|c|c|c|c|c|c|}
\hline Name & Expression & Tumor & Angiogenesis & Metastasis & Target gene & Reference \\
\hline miR-29c & Down & Glioma & Suppression & Suppression & VEGF, MMP2 & 57 \\
\hline miR-195 & Down & Hepatocellular carcinoma & Suppression & Suppression & $\begin{array}{l}\text { VEGF, VAV2, } \\
\text { CDC42 }\end{array}$ & 58 \\
\hline $\operatorname{miR}-199 a-3 p$ & Down & Hepatocellular carcinoma & Suppression & Suppression & $\begin{array}{c}\text { VEGFA, } \\
\text { VEGFR1, } \\
\text { VEGFR2, HGF, } \\
\text { MMP2 }\end{array}$ & 59 \\
\hline $\operatorname{miR}-497$ & Down & $\begin{array}{c}\text { Hepatocellular } \\
\text { carcinoma, breast cancer, } \\
\text { pancreatic cancer }\end{array}$ & Suppression & Suppression & $\begin{array}{l}\text { VEGFA, AEG-1, } \\
\text { VEGFR2 }\end{array}$ & $60,61,62$ \\
\hline $\operatorname{miR}-519 c$ & Down & $\begin{array}{c}\text { Lung adenocarcinoma, } \\
\text { breast cancer }\end{array}$ & Suppression & Suppression & HIF-1alpha & 63 \\
\hline $\operatorname{miR}-145$ & Down & $\begin{array}{l}\text { Gastric cancer, } \\
\text { neuroblastoma }\end{array}$ & Suppression & Suppression & HIF-2alpha, Ets 1 & 64,65 \\
\hline $\operatorname{miR}-107$ & Down & Colon cancer & Suppression & Suppression & $\begin{array}{c}\text { HIF-1beta, VEGF, } \\
\text { BDNF }\end{array}$ & 67 \\
\hline $\operatorname{miR}-542-3 p$ & Down & $\begin{array}{c}\text { Breast cancer, } \\
\text { hepatocellular carcinoma }\end{array}$ & Suppression & Suppression & ANG2 & 71,72 \\
\hline $\operatorname{miR}-543$ & Down & $\begin{array}{c}\text { Osteosarcoma, colorectal } \\
\text { cancer }\end{array}$ & Suppression & Suppression & $\begin{array}{l}\text { ANG2, KRAS, } \\
\text { MTA1, HMGA2 }\end{array}$ & 73,74 \\
\hline $\operatorname{miR}-9$ & Down & Neuroblastoma & Suppression & Suppression & MMP14 & 75 \\
\hline $\operatorname{miR}-181-5 p$ & Down & $\begin{array}{l}\text { Breast cancer, colon } \\
\text { cancer }\end{array}$ & Suppression & Suppression & MMP14 & 76 \\
\hline $\operatorname{miR}-454$ & Down & Pancreatic cancer & Suppression & Suppression & LRP6 & 79 \\
\hline $\operatorname{miR}-126-3 p$ & Down & $\begin{array}{c}\text { Oral squamous } \\
\text { cell carcinoma, } \\
\text { hepatocellular carcinoma }\end{array}$ & Suppression & Suppression & $\begin{array}{l}\text { VEGFA, LRP6, } \\
\text { PIK3R2 }\end{array}$ & 80,81 \\
\hline $\operatorname{miR}-26 a$ & Down & Hepatocellular carcinoma & Suppression & Suppression & IL-6, HGF & 83,84 \\
\hline $\operatorname{miR}-451$ & Down & $\begin{array}{l}\text { Osteosarcoma, } \\
\text { hepatocellular carcinoma }\end{array}$ & Suppression & Suppression & IL-6R & 85,86 \\
\hline $\operatorname{miR}-34 a$ & Down & Bladder cancer & Suppression & Suppression & CD44 & 88 \\
\hline $\operatorname{miR}-101$ & Down & $\begin{array}{c}\text { Glioblastoma, } \\
\text { nasopharygeal carcinoma }\end{array}$ & Suppression & Suppression & EZH2, ITGA3 & 89,90 \\
\hline $\operatorname{miR}-124$ & Down & $\begin{array}{l}\text { Bladder cancer, cervical } \\
\text { cancer }\end{array}$ & Suppression & Suppression & UHRF1, AmotL1 & 91,92 \\
\hline $\operatorname{miR}-135 \mathrm{a}$ & Down & $\begin{array}{l}\text { Gastric cancer, non-small } \\
\text { cell lung cancer }\end{array}$ & Suppression & Suppression & FAK, IGF-1 & 95,96 \\
\hline $\operatorname{miR}-218$ & Down & Gastric cancer & Suppression & Suppression & ROBO1 & 99,100 \\
\hline $\operatorname{miR}-320$ & Down & $\begin{array}{c}\text { Oral squamous } \\
\text { cell carcinoma, } \\
\text { cholangiocarcinoma }\end{array}$ & Suppression & Suppression & Neuropilin 1 & 104,105 \\
\hline miR-409-3p & Down & Fibrosarcoma & Suppression & Suppression & Angiogenin & 108 \\
\hline
\end{tabular}

(Continued) 


\begin{tabular}{lcccccc}
\hline Name & Expression & Tumor & Angiogenesis & Metastasis & Target gene & Reference \\
\hline miR-590-5p & Down & Colorectal cancer & Suppression & Suppression & NF90 & 112 \\
miR-1301 & Down & Hepatocellular carcinoma & Suppression & Suppression & BCL9 & 114 \\
miR-93 & Up & Breast cancer & Promotion & Promotion & Integrin-beta8, & 120,121 \\
& & & & LATS2 & Sufu, Fus-1, & 125,126 \\
miR-378 & Up & Non-small cell lung & Promotion & Promotion & HMOX1 & 129,131 \\
& & cancer & & & VHL, C/EBPbeta & 126 \\
miR-155 & Up & Breast cancer & Promotion & Promotion & NOTCH1, PTEN & 135,136 \\
miR-494 & Up & Lung cancer & Promotion & Promotion & NGS, ICAM1 & 139,142 \\
miR-296 & Up & Prostate cancer & Promotion & Promotion & HGS \\
miR-1246 & Up & Colorectal cancer & Promotion & Promotion & PML, CCNG2 & 145,146 \\
miR-181a & Up & Chondrosarcoma & Promotion & Promotion & RGS16 & 152 \\
miR-221/222 & Up & Thyroid carcinoma, & Promotion & Promotion & ADIPOR1, & 153,156 \\
& & glioma & & & TIMP2 & \\
\hline
\end{tabular}

higher than adjacent normal tissues [147]. Yamada et al. demonstrated that promyelocytic leukemia protein (PML), a tumor suppressor protein required for the assembly of a number of nuclear structures [148] and a regulator of the Smad 2/3 signaling, was a direct target of miRNA-1246 [147]. Besides, CRC cell-derived microvesicles with miRNA-1246 facilitated CRC angiogenesis by downregulating PML. These findings show that miRNA-1246 is a potential therapeutic target to treat colorectal cancer angiogenesis and metastasis.

\section{MiRNA-181a}

MiRNA-181a is associated with T cell sensitivity, vascular development, cerebellar neurodegeneration and diabetes mellitus [149-152]. Sun et al. showed that miRNA-181a is oncogenic and upregulated in high grade chondrosarcoma by hypoxia [153]. The overexpression of miRNA-181a decreased regulator of G-protein signaling 16 (RGS16), which suppresses CXC chemokine receptor 4 (CXCR4) signaling. This resulted in increased expression of VEGF and MMP1 that promote chondrosarcoma angiogenesis and metastasis [153]. Thus, miRNA-181a is a potential therapeutic target for inhibiting chondrosarcoma angiogenesis and metastasis.

\section{MiRNA-221 and miRNA-222}

Epithelial-mesenchymal transition (EMT) in breast cancer is aberrantly activated by overexpression of miRNA-221 and miRNA-222, which target adiponectin receptor 1 (ADIPOR1) [154, 155]. Jikuzono et al. showed that miRNA-221/222 cluster was upregulated in metastatic minimally invasive follicular thyroid carcinoma (MI-FTC) [156]. Yang et al. reported that Tissue inhibitor of metalloproteinase 2 (TIMP2) was a direct target of miRNANA-221/222 in gliomas [157]. TIMP2 overexpression suppressed glioma angiogenesis and metastasis, which was enhanced by miRNA-221/222 [157]. Therefore, miRNA-221 and miRNA-222 are potential targets in the treatment of metastatic follicular thyroid carcinoma.

\section{CONCLUSIONS AND FUTURE PERSPECTIVES}

Metastasis is the main cause of cancer-related deaths and is a big challenge in improving survival of cancer patients. Recent advances in the understanding of mechanisms underlying metastasis have opened up novel avenues to overcome the bottleneck in metastatic cancer therapy. Angiogenesis is a key step in cancer metastasis, which provides the channel for dissemination of cancer cells. Hence, blocking angiogenesis represents an effective therapeutic strategy for metastatic cancer. Anti-angiogenesis drugs have played a primary role in the treatment of a variety of metastatic cancers such as metastatic renal cell carcinoma [158]. However, the outcomes are unsatisfactory due to adverse effects such as bleeding and resistance to anti-angiogenic therapy $[159,160]$. Therefore, novel alternatives of anti-angiogenic therapy are necessary. In the last decade, considerable evidence has accumulated about the involvement of miRNAs in cancer angiogenesis and metastasis. Table 1 shows few selected miRNAs that regulate cancer angiogenesis and metastasis. Studies have shown that dysregulation of these miRNAs greatly impacts cancer angiogenesis and metastasis. Huang et al. demonstrated that miRNA-30a negatively correlated with hematogenous metastasis of clear cell renal cell carcinoma by targeting angiogenesis-specific delta-like 4 (DLL4) [161]. This demonstrated that the regulation of miRNAs in angiogenesis contributed to cancer metastasis. Furthermore, rapid development of miRNA antagonists, mimics and 
delivery technologies has enabled the use of miRNAs in metastatic cancer therapy. However, the direct connection between the role of miRNAs in angiogenesis and cancer metastasis remains to be established. Besides, miRNAbased therapy is still not available in clinical settings. Nevertheless, with greater advances in technology, it is a matter of time before effective miRNA-based therapy is applied in the area of cancer angiogenesis and metastasis.

\section{Abbreviations}

AdipoR1, Adiponectin receptor 1

AMD, Age-related macular degeneration

AmotL1, Angiomotin-like protein 1

Ang, Angiopoietin

BCL9, B-cell CLL/lymphoma 9

$\mathrm{C} / \mathrm{EBP}$ beta, CCAAT-enhancer binding protein beta

CTGF, Connective tissue growth factor

CXCR4, CXC chemokine receptor 4

EMs, Endometriosis

Ets1, V-ets erythroblastosis virus E26 oncogene homolog 1

EZH2, Enhancer of zeste homolog 2

FAK, Focal adhesion kinase

HGS, Hepatocyte growth factor-regulated tyrosine kinase substrate

HIF, Hypoxia-inducible factor

ICAM1, Intercellular adhesion molecule 1

IL-6, Interleukin-6

ITGA3, Integrin subunit alpha 3

LATS2, Large tumor suppressor homology 2

LRP6, Low-density lipoprotein receptor-related protein 6

MMP, Matrix metalloproteinase

NF90, Nuclear factor 90

PDGFR, Platelet-derived growth factor receptor

PGF, Placenta growth factor

PML, Promyelocytic leukemia protein

PTEN, Phosphatase and tensin homologue

RA, Rheumatoid arthritis

RGS16, Regulator of G-protein signaling 16

ROBO1, Roundabout homolog 1

SHH, Sonic hedgehog

$\mathrm{SuFu}$, Suppressor of fused homolog

TIMP2, Tissue inhibitor of metalloproteinase2

UHRF1, Ubiquitin-like with PHD and RING finger domain 1

VEGF, Vascular endothelial growth factor

VHL, Von Hippel-Lindau

VPF, Vascular permeability factor

\section{CONFLICTS OF INTEREST}

The authors declare that there are no conflicts of interest.

\section{FUNDING}

This work was supported by the National Natural Science Foundation of China $(81372462,81572987)$ and Department of Science and Technology of Zhejiang Province (Grant No. 2014C03012).

\section{REFERENCES}

1. Bartel DP. MicroRNAs: genomics, biogenesis, mechanism, and function. Cell. 2004; 116:281-297.

2. Kuehbacher A, Urbich C, Dimmeler S. Targeting microRNA expression to regulate angiogenesis. Trends Pharmacol Sci. 2008; 29:12-15

3. Kim AH, Reimers M, Maher B, Williamson V, McMichael O, McClay JL, van den Oord EJ, Riley BP, Kendler KS, Vladimirov VI. MicroRNA expression profiling in the prefrontal cortex of individuals affected with schizophrenia and bipolar disorders. Schizophr Res. 2010; 124:183-191.

4. Ambros V. The functions of animal microRNAs. Nature. 2004; 431:350-355.

5. Giovannetti E, Erozenci A, Smit J, Danesi R, Peters GJ. Molecular mechanisms underlying the role of microRNAs (miRNAs) in anticancer drug resistance and implications for clinical practice. Crit Rev Oncol Hematol. 2012; 81:103-122.

6. Kumar MS, Armenteros-Monterroso E, East P, Chakravorty P, Matthews N, Winslow MM, Downward J. HMGA2 functions as a competing endogenous RNA to promote lung cancer progression. Nature. 2014; 505:212-217.

7. Winter J, Diederichs S. MicroRNA biogenesis and cancer. Methods Mol Biol. 2011; 676:3-22.

8. Coelho AL, Gomes MP, Catarino RJ, Rolfo C, Lopes AM, Medeiros RM, Araujo AM. Angiogenesis in NSCLC: is vessel co-option the trunk that sustains the branches? Oncotarget. 2017; 8:39795-39804. https://doi.org/10.18632/ oncotarget.7794.

9. Sim EK, Zhang L, Shim WS, Lim YL, Ge R. Therapeutic angiogenesis for coronary artery disease. J Card Surg. 2002; 17:350-354.

10. Wang L, Lee AY, Wigg JP, Peshavariya H, Liu P, Zhang H. miRNA involvement in angiogenesis in age-related macular degeneration. J Physiol Biochem. 2016; 72:583-592.

11. Wang L, Lee AY, Wigg JP, Peshavariya H, Liu P, Zhang H. miR-126 regulation of angiogenesis in age-related macular degeneration in CNV mouse model. Int J Mol Sci. 2016.

12. Chen CY, Su CM, Hsu CJ, Huang CC, Wang SW, Liu $\mathrm{SC}$, Chen WC, Fuh LJ, Tang CH. CCN1 promotes VEGF production in osteoblasts and induces endothelial progenitor cell angiogenesis by inhibiting miR-126 expression in rheumatoid arthritis. J Bone Miner Res. 2017; 32:34-45.

13. Elshabrawy HA, Chen Z, Volin MV, Ravella S, Virupannavar S, Shahrara S. The pathogenic role of 
angiogenesis in rheumatoid arthritis. Angiogenesis. 2015; 18:433-448.

14. Jiang S, Li Y, Lin T, Yuan L, Li Y, Wu S, Xia L, Shen H, Lu J. IL-35 inhibits angiogenesis through VEGF/Ang2/Tie2 pathway in rheumatoid arthritis. Cell Physiol Biochem. 2016; 40:1105-1116.

15. Ozcan Cenksoy P, Oktem M, Erdem O, Karakaya C, Cenksoy C, Erdem A, Guner H, Karabacak O. A potential novel treatment strategy: inhibition of angiogenesis and inflammation by resveratrol for regression of endometriosis in an experimental rat model. Gynecol Endocrinol. 2015; 31:219-224.

16. Soysal D, Kizildag S, Saatli B, Posaci C, Soysal S, Koyuncuoglu M, Dogan O. A novel angiogenesis inhibitor bevacizumab induces apoptosis in the rat endometriosis model. Balkan J Med Genet. 2014; 17:73-80.

17. Folkman J. Angiogenesis in cancer, vascular, rheumatoid and other disease. Nat Med. 1995; 1:27-31.

18. Li S, Ma Y, Xie C, Wu Z, Kang Z, Fang Z, Su B, Guan M. EphA6 promotes angiogenesis and prostate cancer metastasis and is associated with human prostate cancer progression. Oncotarget. 2015; 6:22587-22597. https://doi. org/10.18632/oncotarget.4088.

19. Li Y, Wu Z, Yuan J, Sun L, Lin L, Huang N, Bin J, Liao Y, Liao W. Long non-coding RNA MALAT1 promotes gastric cancer tumorigenicity and metastasis by regulating vasculogenic mimicry and angiogenesis. Cancer Lett. 2017; 395:31-44.

20. Shen J, Zhou S, Shi L, Liu X, Lin H, Yu H, Xiaoliang, Tang J, Yu T, Cai X. DUSP1 inhibits cell proliferation, metastasis and invasion and angiogenesis in gallbladder cancer. Oncotarget. 2017; 8:12133-12144. https://doi. org/10.18632/oncotarget.14815.

21. Xu H, Zhang Y, Pena MM, Pirisi L, Creek KE. Six 1 promotes colorectal cancer growth and metastasis by stimulating angiogenesis and recruiting tumor-associated macrophages. Carcinogenesis. 2017; 38:281-292.

22. McGuire S. World Cancer Report 2014. Geneva, Switzerland: World Health Organization, International Agency for Research on Cancer, WHO Press, 2015. Adv Nutr. 2016; 7:418-419.

23. Monteiro J, Fodde R. Cancer stemness and metastasis: therapeutic consequences and perspectives. Eur J Cancer. 2010; 46:1198-1203.

24. Zeng Y, Cullen BR. Recognition and cleavage of primary microRNA transcripts. Methods Mol Biol. 2006; 342:49-56.

25. Bohnsack MT, Czaplinski K, Gorlich D. Exportin 5 is a RanGTP-dependent dsRNA-binding protein that mediates nuclear export of pre-miRNAs. RNA. 2004; 10:185-191.

26. Lund E, Guttinger S, Calado A, Dahlberg JE, Kutay U. Nuclear export of microRNA precursors. Science. 2004; 303:95-98.
27. Yi R, Qin Y, Macara IG, Cullen BR. Exportin-5 mediates the nuclear export of pre-microRNAs and short hairpin RNAs. Genes Dev. 2003; 17:3011-3016.

28. Carthew RW, Sontheimer EJ. Origins and mechanisms of miRNAs and siRNAs. Cell. 2009; 136:642-655.

29. Pratt AJ, MacRae IJ. The RNA-induced silencing complex: a versatile gene-silencing machine. J Biol Chem. 2009; 284:17897-17901.

30. Wakiyama M, Takimoto K, Ohara O, Yokoyama S. Let-7 microRNA-mediated mRNA deadenylation and translational repression in a mammalian cell-free system. Genes Dev. 2007; 21:1857-1862.

31. Gregory RI, Chendrimada TP, Cooch N, Shiekhattar R. Human RISC couples microRNA biogenesis and posttranscriptional gene silencing. Cell. 2005; 123:631-640.

32. Vasudevan S, Tong Y, Steitz JA. Switching from repression to activation: microRNAs can up-regulate translation. Science. 2007; 318:1931-1934.

33. Folkman J, Browder T, Palmblad J. Angiogenesis research: guidelines for translation to clinical application. Thromb Haemost. 2001; 86:23-33.

34. Carmeliet P, Jain RK. Molecular mechanisms and clinical applications of angiogenesis. Nature. 2011; 473:298-307.

35. Adams RH, Alitalo K. Molecular regulation of angiogenesis and lymphangiogenesis. Nat Rev Mol Cell Biol. 2007; 8:464-478.

36. Heusschen R, van Gink M, Griffioen AW, Thijssen VL. MicroRNAs in the tumor endothelium: novel controls on the angioregulatory switchboard. Biochim Biophys Acta. 2010; 1805:87-96.

37. Wahl ML, Moser TL, Pizzo SV. Angiostatin and antiangiogenic therapy in human disease. Recent Prog Horm Res. 2004; 59:73-104.

38. Lee SH, Jeung IC, Park TW, Lee K, Lee DG, Cho YL, Lee TS, Na HJ, Park YJ, Lee HG, Jeong MS, Bae KH, Lee $\mathrm{SC}$, et al. Extension of the in vivo half-life of endostatin and its improved anti-tumor activities upon fusion to a humanized antibody against tumor-associated glycoprotein 72 in a mouse model of human colorectal carcinoma. Oncotarget. 2015; 6:7182-7194. https://doi.org/10.18632/ oncotarget. 3121.

39. Treps L, Gavard J. [Tumor angiogenesis: when the Tree of Life turns bad]. [Article in French]. Med Sci (Paris). 2015; 31:989-995.

40. Caporali A, Emanueli C. MicroRNA regulation in angiogenesis. Vascul Pharmacol. 2011; 55:79-86.

41. Butler TP, Gullino PM. Quantitation of cell shedding into efferent blood of mammary adenocarcinoma. Cancer Res. 1975; 35:512-516.

42. Yang $\mathrm{X}$, Zhang $\mathrm{Y}$, Hosaka $\mathrm{K}$, Andersson $\mathrm{P}$, Wang J, Tholander F, Cao Z, Morikawa H, Tegner J, Yang Y, Iwamoto $\mathrm{H}$, Lim S, Cao Y. VEGF-B promotes cancer metastasis through a VEGF-A-independent mechanism and 
serves as a marker of poor prognosis for cancer patients. Proc Natl Acad Sci U S A. 2015; 112:E2900-2909.

43. Winter M, Gibson R, Ruszkiewicz A, Thompson SK, Thierry B. Beyond conventional pathology: towards preoperative and intraoperative lymph node staging. Int J Cancer. 2015; 136:743-751.

44. Chan SH, Wang LH. Regulation of cancer metastasis by microRNAs. J Biomed Sci. 2015; 22:9.

45. Jafri MA, Al-Qahtani MH, Shay JW. Role of miRNAs in human cancer metastasis: implications for therapeutic intervention. Semin Cancer Biol. 2017; 44:117-131.

46. Sahoo SS, Quah MY, Nielsen S, Atkins J, Au GG, Cairns MJ, Nahar P, Lombard JM, Tanwar PS. Inhibition of extracellular matrix mediated TGF-beta signalling suppresses endometrial cancer metastasis. Oncotarget. 2017; 8:71400-71417. https://doi.org/10.18632/oncotarget.18069.

47. Tang Q, Liu Y, Li T, Yang X, Zheng G, Chen H, Jia L, Shao J. A novel co-drug of aspirin and ursolic acid interrupts adhesion, invasion and migration of cancer cells to vascular endothelium via regulating EMT and EGFR-mediated signaling pathways: multiple targets for cancer metastasis prevention and treatment. Oncotarget. 2016; 7:73114 73129. https://doi.org/10.18632/oncotarget.12232.

48. Xu X, Yan Q, Wang Y, Dong X. NTN4 is associated with breast cancer metastasis via regulation of EMT-related biomarkers. Oncol Rep. 2017; 37:449-457.

49. Zhang C, Wang Y, Feng Y, Zhang Y, Ji B, Wang S, Sun Y, Zhu C, Zhang D, Sun Y. Gli1 promotes colorectal cancer metastasis in a Foxm1-dependent manner by activating EMT and PI3K-AKT signaling. Oncotarget. 2016; 7:8613486147. https://doi.org/10.18632/oncotarget.13348.

50. Lubbe WJ, Zuzga DS, Zhou Z, Fu W, Pelta-Heller J, Muschel RJ, Waldman SA, Pitari GM. Guanylyl cyclase $\mathrm{C}$ prevents colon cancer metastasis by regulating tumor epithelial cell matrix metalloproteinase-9. Cancer Res. 2009; 69:3529-3536.

51. Zuzga DS, Gibbons AV, Li P, Lubbe WJ, Chervoneva I, Pitari GM. Overexpression of matrix metalloproteinase 9 in tumor epithelial cells correlates with colorectal cancer metastasis. Clin Transl Sci. 2008; 1:136-141.

52. Schirrmacher V, Fogel M, Russmann E, Bosslet K, Altevogt $\mathrm{P}$, Beck L. Antigenic variation in cancer metastasis: immune escape versus immune control. Cancer Metastasis Rev. 1982; $1: 241-274$

53. Chen C, Song G, Xiang J, Zhang H, Zhao S, Zhan Y. AURKA promotes cancer metastasis by regulating epithelial-mesenchymal transition and cancer stem cell properties in hepatocellular carcinoma. Biochem Biophys Res Commun. 2017; 486:514-520.

54. Xie HY, Shao ZM, Li DQ. Tumor microenvironment: driving forces and potential therapeutic targets for breast cancer metastasis. Chin J Cancer. 2017; 36:36.

55. Ferrara N, Gerber HP, LeCouter J. The biology of VEGF and its receptors. Nat Med. 2003; 9:669-676.
56. Sinha S, Khan S, Shukla S, Lakra AD, Kumar S, Das G, Maurya R, Meeran SM. Cucurbitacin B inhibits breast cancer metastasis and angiogenesis through VEGFmediated suppression of FAK/MMP-9 signaling axis. Int J Biochem Cell Biol. 2016; 77:41-56.

57. Yu W, Chen L, Yang YQ, Falck JR, Guo AM, Li Y, Yang J. Cytochrome P450 omega-hydroxylase promotes angiogenesis and metastasis by upregulation of VEGF and MMP-9 in non-small cell lung cancer. Cancer Chemother Pharmacol. 2011; 68:619-629.

58. Fan YC, Mei PJ, Chen C, Miao FA, Zhang H, Li ZL. MiR-29c inhibits glioma cell proliferation, migration, invasion and angiogenesis. J Neurooncol. 2013; 115:179-188.

59. Wang R, Zhao N, Li S, Fang JH, Chen MX, Yang J, Jia WH, Yuan Y, Zhuang SM. MicroRNA-195 suppresses angiogenesis and metastasis of hepatocellular carcinoma by inhibiting the expression of VEGF, VAV2, and CDC42. Hepatology. 2013; 58:642-653.

60. Ghosh A, Dasgupta D, Ghosh A, Roychoudhury S, Kumar D, Gorain M, Butti R, Datta S, Agarwal S, Gupta S, Krishna Dhali G, Chowdhury A, Schmittgen TD, et al. MiRNA199a-3p suppresses tumor growth, migration, invasion and angiogenesis in hepatocellular carcinoma by targeting VEGFA, VEGFR1, VEGFR2, HGF and MMP2. Cell Death Dis. 2017; 8:e2706.

61. Tu Y, Liu L, Zhao D, Liu Y, Ma X, Fan Y, Wan L, Huang T, Cheng Z, Shen B. Overexpression of miRNA-497 inhibits tumor angiogenesis by targeting VEGFR2. Sci Rep. 2015; $5: 13827$.

62. Liu A, Huang C, Cai X, Xu J, Yang D. Twist promotes angiogenesis in pancreatic cancer by targeting miR-497/ VEGFA axis. Oncotarget. 2016; 7:25801-25814. https:// doi.org/10.18632/oncotarget.8269.

63. Yan JJ, Zhang YN, Liao JZ, Ke KP, Chang Y, Li PY, Wang M, Lin JS, He XX. MiR-497 suppresses angiogenesis and metastasis of hepatocellular carcinoma by inhibiting VEGFA and AEG-1. Oncotarget. 2015; 6:29527-29542. https://doi.org/10.18632/oncotarget.5012.

64. Cha ST, Chen PS, Johansson G, Chu CY, Wang MY, Jeng YM, Yu SL, Chen JS, Chang KJ, Jee SH, Tan CT, Lin MT, Kuo ML. MicroRNA-519c suppresses hypoxia-inducible factor-1alpha expression and tumor angiogenesis. Cancer Res. 2010; 70:2675-2685.

65. Zhang H, Pu J, Qi T, Qi M, Yang C, Li S, Huang K, Zheng L, Tong Q. MicroRNA-145 inhibits the growth, invasion, metastasis and angiogenesis of neuroblastoma cells through targeting hypoxia-inducible factor 2 alpha. Oncogene. 2014; 33:387-397.

66. Zheng L, Pu J, Qi T, Qi M, Li D, Xiang X, Huang K, Tong Q. miRNA-145 targets v-ets erythroblastosis virus E26 oncogene homolog 1 to suppress the invasion, metastasis, and angiogenesis of gastric cancer cells. Mol Cancer Res. 2013; 11:182-193. 
67. Yu JL, Rak JW, Coomber BL, Hicklin DJ, Kerbel RS. Effect of p53 status on tumor response to antiangiogenic therapy. Science. 2002; 295:1526-1528.

68. Yamakuchi M, Lotterman CD, Bao C, Hruban RH, Karim B, Mendell JT, Huso D, Lowenstein CJ. P53-induced microRNA-107 inhibits HIF-1 and tumor angiogenesis. Proc Natl Acad Sci U S A. 2010; 107:6334-6339.

69. Huang H, Bhat A, Woodnutt G, Lappe R. Targeting the ANGPT-TIE2 pathway in malignancy. Nat Rev Cancer. $2010 ; 10: 575-585$.

70. Huang Y, Song N, Ding Y, Yuan S, Li X, Cai H, Shi H, Luo Y. Pulmonary vascular destabilization in the premetastatic phase facilitates lung metastasis. Cancer Res. 2009; 69:7529-7537.

71. Mazzieri R, Pucci F, Moi D, Zonari E, Ranghetti A, Berti A, Politi LS, Gentner B, Brown JL, Naldini L, De Palma M. Targeting the ANG2/TIE2 axis inhibits tumor growth and metastasis by impairing angiogenesis and disabling rebounds of proangiogenic myeloid cells. Cancer Cell. 2011; 19:512-526.

72. He T, Qi F, Jia L, Wang S, Song N, Guo L, Fu Y, Luo Y. MicroRNA-542-3p inhibits tumour angiogenesis by targeting angiopoietin-2. J Pathol. 2014; 232:499-508.

73. Tao J, Liu Z, Wang Y, Wang L, Yao B, Li Q, Wang C, Tu K, Liu Q. MiR-542-3p inhibits metastasis and epithelialmesenchymal transition of hepatocellular carcinoma by targeting UBE3C. Biomed Pharmacother. 2017; 93:420-428.

74. Fan C, Lin Y, Mao Y, Huang Z, Liu AY, Ma H, Yu D, Maitikabili A, Xiao H, Zhang C, Liu F, Luo Q, Ouyang G. MicroRNA-543 suppresses colorectal cancer growth and metastasis by targeting KRAS, MTA1 and HMGA2. Oncotarget. 2016; 7:21825-21839. https://doi.org/10.18632/ oncotarget.7989.

75. Wang LH, Tsai HC, Cheng YC, Lin CY, Huang YL, Tsai $\mathrm{CH}, \mathrm{Xu} \mathrm{GH}$, Wang SW, Fong YC, Tang CH. CTGF promotes osteosarcoma angiogenesis by regulating miR543/angiopoietin 2 signaling. Cancer Lett. 2017; 391:28-37.

76. Zhang H, Qi M, Li S, Qi T, Mei H, Huang K, Zheng L, Tong Q. microRNA-9 targets matrix metalloproteinase 14 to inhibit invasion, metastasis, and angiogenesis of neuroblastoma cells. Mol Cancer Ther. 2012; 11:1454-1466.

77. Li Y, Kuscu C, Banach A, Zhang Q, Pulkoski-Gross A, Kim D, Liu J, Roth E, Li E, Shroyer KR, Denoya PI, Zhu X, Chen L, Cao J. miR-181a-5p inhibits cancer cell migration and angiogenesis via downregulation of matrix metalloproteinase-14. Cancer Res. 2015; 75:2674-2685

78. Williams BO, Insogna KL. Where Wnts went: the exploding field of Lrp5 and Lrp6 signaling in bone. J Bone Miner Res. 2009; 24:171-178.

79. Ma J, Lu W, Chen D, Xu B, Li Y. Role of Wnt co-receptor LRP6 in triple negative breast cancer cell migration and invasion. 2017; 118:2968-2976.
80. Fan Y, Shi C, Li T, Kuang T. microRNA-454 shows antiangiogenic and anti-metastatic activity in pancreatic ductal adenocarcinoma by targeting LRP6. Am J Cancer Res. 2017; 7:139-147.

81. Du C, Lv Z, Cao L, Ding C, Gyabaah OA, Xie H, Zhou L, $\mathrm{Wu}$ J, Zheng S. MiR-126-3p suppresses tumor metastasis and angiogenesis of hepatocellular carcinoma by targeting LRP6 and PIK3R2. J Transl Med. 2014; 12:259.

82. Sasahira T, Kurihara M, Bhawal UK, Ueda N, Shimomoto T, Yamamoto K, Kirita T, Kuniyasu H. Downregulation of miR-126 induces angiogenesis and lymphangiogenesis by activation of VEGF-A in oral cancer. Br J Cancer. 2012; 107:700-706.

83. Miao JW, Liu LJ, Huang J. Interleukin-6-induced epithelialmesenchymal transition through signal transducer and activator of transcription 3 in human cervical carcinoma. Int J Oncol. 2014; 45:165-176.

84. Yang X, Liang L, Zhang XF, Jia HL, Qin Y, Zhu XC, Gao XM, Qiao P, Zheng Y, Sheng YY, Wei JW, Zhou HJ, Ren N, et al. MicroRNA-26a suppresses tumor growth and metastasis of human hepatocellular carcinoma by targeting interleukin-6-Stat3 pathway. Hepatology. 2013; 58:158-170

85. Yang X, Zhang XF, Lu X, Jia HL, Liang L, Dong QZ, Ye QH, Qin LX. MicroRNA-26a suppresses angiogenesis in human hepatocellular carcinoma by targeting hepatocyte growth factor-cMet pathway. Hepatology. 2014; 59:1874-1885.

86. Liu SY, Deng SY, He YB, Ni GX. miR-451 inhibits cell growth, migration and angiogenesis in human osteosarcoma via down-regulating IL 6R. Biochem Biophys Res Commun. 2017; 482:987-993.

87. Liu X, Zhang A, Xiang J, Lv Y, Zhang X. miR-451 acts as a suppressor of angiogenesis in hepatocellular carcinoma by targeting the IL-6R-STAT3 pathway. Oncol Rep. 2016; $36: 1385-1392$

88. Li W, Jia H, Wang J, Guan H, Li Y, Zhang D, Tang Y, Wang TD, Lu S. A CD44-specific peptide, RP-1, exhibits capacities of assisting diagnosis and predicting prognosis of gastric cancer. Oncotarget. 2017; 8:30063-30076. https:// doi.org/10.18632/oncotarget.16275.

89. Yu G, Yao W, Xiao W, Li H, Xu H, Lang B. MicroRNA-34a functions as an anti-metastatic microRNA and suppresses angiogenesis in bladder cancer by directly targeting CD44. J Exp Clin Cancer Res. 2014; 33:779.

90. Smits M, Nilsson J, Mir SE, van der Stoop PM, Hulleman E, Niers JM, de Witt Hamer PC, Marquez VE, Cloos J, Krichevsky AM, Noske DP, Tannous BA, Wurdinger T. miR-101 is down-regulated in glioblastoma resulting in EZH2-induced proliferation, migration, and angiogenesis. Oncotarget. 2010; 1:710-720. https://doi.org/10.18632/ oncotarget.205.

91. Tang XR, Wen X, He QM, Li YQ, Ren XY, Yang XJ, Zhang J, Wang YQ, Ma J, Liu N. MicroRNA-101 inhibits invasion 
and angiogenesis through targeting ITGA3 and its systemic delivery inhibits lung metastasis in nasopharyngeal carcinoma. Cell Death Dis. 2017; 8:e2566.

92. Wang X, Wu Q, Xu B, Wang P, Fan W, Cai Y, Gu X, Meng F. MiR-124 exerts tumor suppressive functions on the cell proliferation, motility and angiogenesis of bladder cancer by fine-tuning UHRF1. FEBS J. 2015; 282:4376-4388.

93. Wan HY, Li QQ, Zhang Y, Tian W, Li YN, Liu M, Li X, Tang H. MiR-124 represses vasculogenic mimicry and cell motility by targeting amotL1 in cervical cancer cells. Cancer Lett. 2014; 355:148-158.

94. Kroiss A, Vincent S, Decaussin-Petrucci M, Meugnier E, Viallet J, Ruffion A, Chalmel F, Samarut J, Allioli N. Androgen-regulated microRNA-135a decreases prostate cancer cell migration and invasion through downregulating ROCK1 and ROCK2. Oncogene. 2015; 34:2846-2855.

95. Zhou H, Guo W, Zhao Y, Wang Y, Zha R, Ding J, Liang L, Yang G, Chen Z, Ma B, Yin B. MicroRNA-135a acts as a putative tumor suppressor by directly targeting very low density lipoprotein receptor in human gallbladder cancer. Cancer Sci. 2014; 105:956-965.

96. Cheng Z, Liu F, Zhang H, Li X, Li Y, Li J, Liu F, Cao Y, Cao L, Li F. miR-135a inhibits tumor metastasis and angiogenesis by targeting FAK pathway. Oncotarget. 2017; 8:31153-31168. https://doi.org/10.18632/oncotarget.16098.

97. Zhou Y, Li S, Li J, Wang D, Li Q. Effect of microRNA-135a on cell proliferation, migration, invasion, apoptosis and tumor angiogenesis through the IGF-1/PI3K/Akt signaling pathway in non-small cell lung cancer. Cell Physiol Biochem. 2017; 42:1431-1446.

98. Alajez NM, Lenarduzzi M, Ito E, Hui AB, Shi W, Bruce J, Yue S, Huang SH, Xu W, Waldron J, O’Sullivan B, Liu FF. MiR-218 suppresses nasopharyngeal cancer progression through downregulation of survivin and the SLIT2-ROBO1 pathway. Cancer Res. 2011; 71:2381-2391.

99. Uesugi A, Kozaki K, Tsuruta T, Furuta M, Morita K, Imoto I, Omura K, Inazawa J. The tumor suppressive microRNA miR-218 targets the mTOR component Rictor and inhibits AKT phosphorylation in oral cancer. Cancer Res. 2011; 71:5765-5778.

100. Zhang X, Dong J, He Y, Zhao M, Liu Z, Wang N, Jiang M, Zhang Z, Liu G, Liu H, Nie Y, Fan D, Tie J. miR-218 inhibited tumor angiogenesis by targeting ROBO1 in gastric cancer. Gene. 2017; 615:42-49.

101. Tie J, Pan Y, Zhao L, Wu K, Liu J, Sun S, Guo X, Wang B, Gang Y, Zhang Y, Li Q, Qiao T, Zhao Q, Nie Y, Fan D. MiR-218 inhibits invasion and metastasis of gastric cancer by targeting the Robo1 receptor. PLoS Genet. 2010; 6:e1000879.

102. Parikh AA, Fan F, Liu WB, Ahmad SA, Stoeltzing O, Reinmuth N, Bielenberg D, Bucana CD, Klagsbrun M, Ellis LM. Neuropilin-1 in human colon cancer: expression, regulation, and role in induction of angiogenesis. Am J Pathol. 2004; 164:2139-2151.
103. Soker S, Takashima S, Miao HQ, Neufeld G, Klagsbrun M. Neuropilin-1 is expressed by endothelial and tumor cells as an isoform-specific receptor for vascular endothelial growth factor. Cell. 1998; 92:735-745.

104. Tse BW, Volpert M, Ratther E, Stylianou N, Nouri M, McGowan K, Lehman ML, McPherson SJ, Roshan-Moniri M, Butler MS, Caradec J, Gregory-Evans CY, McGovern J, et al. Neuropilin-1 is upregulated in the adaptive response of prostate tumors to androgen-targeted therapies and is prognostic of metastatic progression and patient mortality. Oncogene. 2017; 36:3417-3427.

105. Wu YY, Chen YL, Jao YC, Hsieh IS, Chang KC, Hong TM. miR-320 regulates tumor angiogenesis driven by vascular endothelial cells in oral cancer by silencing neuropilin 1 . Angiogenesis. 2014; 17:247-260.

106. Zhu H, Jiang X, Zhou X, Dong X, Xie K, Yang C, Jiang H, Sun X. Neuropilin-1 regulated by miR-320 contributes to the growth and metastasis of cholangiocarcinoma cells. Liver Int. 2017.

107. Chen Y, Zhang S, Chen YP, Lin JY. Increased expression of angiogenin in gastric carcinoma in correlation with tumor angiogenesis and proliferation. World J Gastroenterol. 2006; 12:5135-5139.

108. Schwartz B, Shoseyov O, Melnikova VO, McCarty M, Leslie M, Roiz L, Smirnoff P, Hu GF, Lev D, Bar-Eli M. ACTIBIND, a T2 RNase, competes with angiogenin and inhibits human melanoma growth, angiogenesis, and metastasis. Cancer Res. 2007; 67:5258-5266.

109. Weng C, Dong H, Chen G, Zhai Y, Bai R, Hu H, Lu L, $\mathrm{Xu}$ Z. miR-409-3p inhibits HT1080 cell proliferation, vascularization and metastasis by targeting angiogenin. Cancer Lett. 2012; 323:171-179.

110. Ou C, Sun Z, Li X, Li X, Ren W, Qin Z, Zhang X, Yuan W, Wang J, Yu W, Zhang S, Peng Q, Yan Q, et al. MiR-590-5p, a density-sensitive microRNA, inhibits tumorigenesis by targeting YAP1 in colorectal cancer. Cancer Lett. 2017; 399:53-63.

111. Shen B, Yu S, Zhang Y, Yuan Y, Li X, Zhong J, Feng J. miR-590-5p regulates gastric cancer cell growth and chemosensitivity through RECK and the AKT/ERK pathway. Onco Targets Ther. 2016; 9:6009-6019.

112. Zhou L, Zhao LC, Jiang N, Wang XL, Zhou XN, Luo XL, Ren J. MicroRNA miR-590-5p inhibits breast cancer cell stemness and metastasis by targeting SOX2. Eur Rev Med Pharmacol Sci. 2017; 21:87-94.

113. Zhou Q, Zhu Y, Wei X, Zhou J, Chang L, Sui H, Han Y, Piao D, Sha R, Bai Y. MiR-590-5p inhibits colorectal cancer angiogenesis and metastasis by regulating nuclear factor $90 /$ vascular endothelial growth factor A axis. Cell Death Dis. 2016; 7:e2413.

114. Wang B, Wu H, Chai C, Lewis J, Pichiorri F, Eisenstat DD, Pomeroy SL, Leng RP. MicroRNA-1301 suppresses tumor cell migration and invasion by targeting the p53/UBE4B pathway in multiple human cancer cells. Cancer Lett. 2017; 401:20-32. 
115. Yang C, Xu Y, Cheng F, Hu Y, Yang S, Rao J, Wang X. miR-1301 inhibits hepatocellular carcinoma cell migration, invasion, and angiogenesis by decreasing Wnt/beta-catenin signaling through targeting BCL9. Cell Death Dis. 2017; 8:e2999.

116. Mosimann C, Hausmann G, Basler K. Beta-catenin hits chromatin: regulation of Wnt target gene activation. Nat Rev Mol Cell Biol. 2009; 10:276-286.

117. Tanzer A, Stadler PF. Molecular evolution of a microRNA cluster. J Mol Biol. 2004; 339:327-335.

118. Ventura A, Young AG, Winslow MM, Lintault L, Meissner A, Erkeland SJ, Newman J, Bronson RT, Crowley D, Stone JR, Jaenisch R, Sharp PA, Jacks T. Targeted deletion reveals essential and overlapping functions of the miR-17 through 92 family of miRNA clusters. Cell. 2008; 132:875-886.

119. Kan T, Sato F, Ito T, Matsumura N, David S, Cheng Y, Agarwal R, Paun BC, Jin Z, Olaru AV, Selaru FM, Hamilton JP, Yang J, et al. The miR-106b-25 polycistron, activated by genomic amplification, functions as an oncogene by suppressing p21 and Bim. Gastroenterology. 2009; 136:1689-1700.

120. Semo J, Sharir R, Afek A, Avivi C, Barshack I, MayselAuslender S, Krelin Y, Kain D, Entin-Meer M, Keren G, George J. The 106b approximately 25 microRNA cluster is essential for neovascularization after hindlimb ischaemia in mice. Eur Heart J. 2014; 35:3212-3223.

121. Fang L, Deng Z, Shatseva T, Yang J, Peng C, Du WW, Yee AJ, Ang LC, He C, Shan SW, Yang BB. MicroRNA miR93 promotes tumor growth and angiogenesis by targeting integrin-beta8. Oncogene. 2011; 30:806-821.

122. Fang L, Du WW, Yang W, Rutnam ZJ, Peng C, Li H, O’Malley YQ, Askeland RW, Sugg S, Liu M, Mehta T, Deng Z, Yang BB. MiR-93 enhances angiogenesis and metastasis by targeting LATS2. Cell Cycle. 2012; 11:4352-4365.

123. Skrzypek K, Tertil M, Golda S, Ciesla M, Weglarczyk K, Collet G, Guichard A, Kozakowska M, Boczkowski J, Was H, Gil T, Kuzdzal J, Muchova L, et al. Interplay between heme oxygenase- 1 and miR-378 affects non-small cell lung carcinoma growth, vascularization, and metastasis. Antioxid Redox Signal. 2013; 19:644-660.

124. Qian J, Lin J, Qian W, Ma JC, Qian SX, Li Y, Yang J, Li JY, Wang CZ, Chai HY, Chen XX, Deng ZQ. Overexpression of miR-378 is frequent and may affect treatment outcomes in patients with acute myeloid leukemia. Leuk Res. 2013; 37:765-768.

125. Redova M, Poprach A, Nekvindova J, Iliev R, Radova L, Lakomy R, Svoboda M, Vyzula R, Slaby O. Circulating miR-378 and miR-451 in serum are potential biomarkers for renal cell carcinoma. J Transl Med. 2012; 10:55.

126. Lee DY, Deng Z, Wang CH, Yang BB. MicroRNA-378 promotes cell survival, tumor growth, and angiogenesis by targeting SuFu and Fus-1 expression. Proc Natl Acad Sci U S A. 2007; 104:20350-20355.
127. Chen LT, Xu SD, Xu H, Zhang JF, Ning JF, Wang SF. MicroRNA-378 is associated with non-small cell lung cancer brain metastasis by promoting cell migration, invasion and tumor angiogenesis. Med Oncol. 2012; 29:1673-1680.

128. Iorio MV, Ferracin M, Liu CG, Veronese A, Spizzo R, Sabbioni S, Magri E, Pedriali M, Fabbri M, Campiglio M, Menard S, Palazzo JP, Rosenberg A, et al. MicroRNA gene expression deregulation in human breast cancer. Cancer Res. 2005; 65:7065-7070.

129. Yanaihara N, Caplen N, Bowman E, Seike M, Kumamoto K, Yi M, Stephens RM, Okamoto A, Yokota J, Tanaka T, Calin GA, Liu CG, Croce CM, Harris CC. Unique microRNA molecular profiles in lung cancer diagnosis and prognosis. Cancer Cell. 2006; 9:189-198.

130. Kong W, He L, Richards EJ, Challa S, Xu CX, PermuthWey J, Lancaster JM, Coppola D, Sellers TA, Djeu JY, Cheng JQ. Upregulation of miRNA-155 promotes tumour angiogenesis by targeting VHL and is associated with poor prognosis and triple-negative breast cancer. Oncogene. 2014; 33:679-689.

131. Kurban G, Hudon V, Duplan E, Ohh M, Pause A. Characterization of a von Hippel Lindau pathway involved in extracellular matrix remodeling, cell invasion, and angiogenesis. Cancer Res. 2006; 66:1313-1319.

132. Petrovic N, Kolakovic A, Stankovic A, Lukic S, Rami A, Ivkovic M, Mandusic V. MiR-155 expression level changes might be associated with initial phases of breast cancer pathogenesis and lymph-node metastasis. Cancer Biomark. 2016; 16:385-394.

133. Johansson J, Berg T, Kurzejamska E, Pang MF, Tabor V, Jansson M, Roswall P, Pietras K, Sund M, Religa P, Fuxe J. MiR-155-mediated loss of C/EBPbeta shifts the TGF-beta response from growth inhibition to epithelial-mesenchymal transition, invasion and metastasis in breast cancer. Oncogene. 2013; 32:5614-5624.

134. Bai Y, Sun Y, Peng J, Liao H, Gao H, Guo Y, Guo L. Overexpression of secretagogin inhibits cell apoptosis and induces chemoresistance in small cell lung cancer under the regulation of miR-494. Oncotarget. 2014; 5:7760-7775. https://doi.org/10.18632/oncotarget.2305.

135. Macedo T, Silva-Oliveira RJ, Silva VA, Vidal DO, Evangelista AF, Marques MM. Overexpression of mir-183 and mir-494 promotes proliferation and migration in human breast cancer cell lines. Oncol Lett. 2017; 14:1054-1060.

136. Faversani A, Amatori S, Augello C, Colombo F, Porretti L, Fanelli M, Ferrero S, Palleschi A, Pelicci PG, Belloni E, Ercoli G, Degrassi A, Baccarin M, et al. miR494-3p is a novel tumor driver of lung carcinogenesis. Oncotarget. 2017; 8:7231-7247. https://doi.org/10.18632/ oncotarget. 13933.

137. Mao G, Liu Y, Fang X, Liu Y, Fang L, Lin L, Liu X, Wang N. Tumor-derived microRNA-494 promotes angiogenesis 
in non-small cell lung cancer. Angiogenesis. 2015; 18:373-382.

138. Batchelor TT, Sorensen AG, di Tomaso E, Zhang WT, Duda DG, Cohen KS, Kozak KR, Cahill DP, Chen PJ, Zhu M, Ancukiewicz M, Mrugala MM, Plotkin S, et al. AZD2171, a pan-VEGF receptor tyrosine kinase inhibitor, normalizes tumor vasculature and alleviates edema in glioblastoma patients. Cancer Cell. 2007; 11:83-95.

139. Shih AH, Holland EC. Platelet-derived growth factor (PDGF) and glial tumorigenesis. Cancer Lett. 2006; 232:139-147.

140. Wurdinger T, Tannous BA, Saydam O, Skog J, Grau S, Soutschek J, Weissleder R, Breakefield XO, Krichevsky AM. miR-296 regulates growth factor receptor overexpression in angiogenic endothelial cells. Cancer Cell. 2008; 14:382-393.

141. Ewan LC, Jopling HM, Jia H, Mittar S, Bagherzadeh A, Howell GJ, Walker JH, Zachary IC, Ponnambalam S. Intrinsic tyrosine kinase activity is required for vascular endothelial growth factor receptor 2 ubiquitination, sorting and degradation in endothelial cells. Traffic. 2006; 7:1270-1282.

142. Takata H, Kato M, Denda K, Kitamura N. A hrs binding protein having a Src homology 3 domain is involved in intracellular degradation of growth factors and their receptors. Genes Cells. 2000; 5:57-69.

143. Liu X, Chen Q, Yan J, Wang Y, Zhu C, Chen C, Zhao X, Xu M, Sun Q, Deng R, Zhang H, Qu Y, Huang J, et al. MiRNA296-3p-ICAM-1 axis promotes metastasis of prostate cancer by possible enhancing survival of natural killer cell-resistant circulating tumour cells. Cell Death Dis. 2013; 4:e928.

144. Liao JM, Zhou X, Zhang Y, Lu H. MiR-1246: a new link of the p53 family with cancer and down syndrome. Cell Cycle. 2012; 11:2624-2630.

145. Piepoli A, Tavano F, Copetti M, Mazza T, Palumbo O, Panza A, di Mola FF, Pazienza V, Mazzoccoli G, Biscaglia G, Gentile A, Mastrodonato N, Carella M, et al. Mirna expression profiles identify drivers in colorectal and pancreatic cancers. PLoS One. 2012; 7:e33663.

146. Wang S, Zeng Y, Zhou JM, Nie SL, Peng Q, Gong J, Huo JR. MicroRNA-1246 promotes growth and metastasis of colorectal cancer cells involving $\mathrm{CCNG} 2$ reduction. Mol Med Rep. 2016; 13:273-280.

147. Yamada N, Tsujimura N, Kumazaki M, Shinohara $\mathrm{H}$, Taniguchi K, Nakagawa $\mathrm{Y}$, Naoe $\mathrm{T}$, Akao $\mathrm{Y}$. Colorectal cancer cell-derived microvesicles containing microRNA-1246 promote angiogenesis by activating Smad 1/5/8 signaling elicited by PML down-regulation in endothelial cells. Biochim Biophys Acta. 2014; 1839:1256-1272.

148. Bernardi R, Pandolfi PP. Structure, dynamics and functions of promyelocytic leukaemia nuclear bodies. Nat Rev Mol Cell Biol. 2007; 8:1006-1016.
149. Kazenwadel J, Michael MZ, Harvey NL. Prox1 expression is negatively regulated by miR-181 in endothelial cells. Blood. 2010; 116:2395-2401.

150. Kloting N, Berthold S, Kovacs P, Schon MR, Fasshauer M, Ruschke K, Stumvoll M, Bluher M. MicroRNA expression in human omental and subcutaneous adipose tissue. PLoS One. 2009; 4:e4699.

151. Li QJ, Chau J, Ebert PJ, Sylvester G, Min H, Liu G, Braich R, Manoharan M, Soutschek J, Skare P, Klein LO, Davis MM, Chen CZ. miR-181a is an intrinsic modulator of $\mathrm{T}$ cell sensitivity and selection. Cell. 2007; 129:147-161.

152. Schaefer A, O'Carroll D, Tan CL, Hillman D, Sugimori M, Llinas R, Greengard P. Cerebellar neurodegeneration in the absence of microRNAs. J Exp Med. 2007; 204:1553-1558.

153. Sun X, Charbonneau C, Wei L, Chen Q, Terek RM. miR181a targets RGS16 to promote chondrosarcoma growth, angiogenesis, and metastasis. Mol Cancer Res. 2015; 13:1347-1357.

154. Hwang MS, Yu N, Stinson SY, Yue P, Newman RJ, Allan BB, Dornan D. miR-221/222 targets adiponectin receptor 1 to promote the epithelial-to-mesenchymal transition in breast cancer. PLoS One. 2013; 8:e66502.

155. Shah MY, Calin GA. MicroRNAs miR-221 and miR-222: a new level of regulation in aggressive breast cancer. Genome Med. 2011; 3:56.

156. Jikuzono T, Kawamoto M, Yoshitake H, Kikuchi K, Akasu H, Ishikawa H, Hirokawa M, Miyauchi A, Tsuchiya S, Shimizu K, Takizawa T. The miR-221/222 cluster, miR-10b and miR-92a are highly upregulated in metastatic minimally invasive follicular thyroid carcinoma. Int J Oncol. 2013; 42:1858-1868.

157. Yang F, Wang W, Zhou C, Xi W, Yuan L, Chen X, Li Y, Yang A, Zhang J, Wang T. MiR-221/222 promote human glioma cell invasion and angiogenesis by targeting TIMP2. Tumour Biol. 2015; 36:3763-3773.

158. Zarrabi K, Fang C, Wu S. New treatment options for metastatic renal cell carcinoma with prior anti-angiogenesis therapy. J Hematol Oncol. 2017; 10:38.

159. Bergers G, Hanahan D. Modes of resistance to antiangiogenic therapy. Nat Rev Cancer. 2008; 8:592-603.

160. Casanovas O. Cancer: limitations of therapies exposed. Nature. 2012; 484:44-46.

161. Huang QB, Ma X, Zhang X, Liu SW, Ai Q, Shi TP, Zhang Y, Gao Y, Fan Y, Ni D, Wang BJ, Li HZ, Zheng T. Downregulated miR-30a in clear cell renal cell carcinoma correlated with tumor hematogenous metastasis by targeting angiogenesis-specific DLL4. PLoS One. 2013; 8:e67294. 